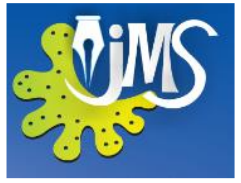

\title{
Characterization of Some ex situ Conserved Finger Millet (Eleusine coracana (L.)) Germplasm Accessions in Sri Lanka
}

\author{
Dasanayaka PN
}

Department of Botany, University of Sri Jayewardenepura, Nugegoda, Sri Lanka

\begin{abstract}
Finger millet (Eleusine coracana (L.) Gaertn.) is a highly nutritious and important food crop widely cultivated in the arid and semiarid regions in the world. Therefore it is worthy to be subjected to crop improvement programs. Germplasm collection and characterization are preliminary and important steps in crop improvement programmes. This study was conducted to characterize randomly selected 24 finger millet germplasm accessions conserved at the plant Genetic Resource Centre, Gannoruwa, Sri Lanka using 14 quantitative characters. The maximum positive and significant coefficient of variation was observed between weight of grain per ear and weight of sun dried ear. Phenotypic correlation between weight of grain per ear was highly significant and positively associated with days to flowering, flag leaf width, flag leaf length, plant height, culm thickness, finger length, finger width, days to maturity and weight of sun dried ears, flag leaf width, flag leaf length, plant height, culm thickness, finger length, finger width, days to maturity and weight of sun dried ears. The principal component analysis revealed that the first five component with Eigen values greater than 0.87 contributed about $85.5 \%$ of total variability. The twenty for finger millet accessions grouped in to four main clusters in the cluster analysis. Results of cluster analysis could be used in the crop breeding and conservation programmes.
\end{abstract}

KEYWORDS: Finger millet, germplasm accessions, genetic diversity, principal component analysis, quantitative characters

Corresponding author: P. N. Dasanayaka, Email: nilanthiedas@sjp.ac.lk 


\section{INTRODUCTION}

Finger millet (Eleusine coracana (L.) Gaertn.) is an allotetraploid $(2 n=4 x=36)$ of the family Poaceae and subfamily, Chloridoideae and is commonly known as "Kurakkan" or "Kurahan" in Sri Lanka. It is an important food crop widely cultivated in the arid and semiarid regions of the world. It is native to Ethiopia and was introduced to India about 3000 years ago. Finger millet has been cultivated in Sri Lanka since ancient times and considered as the second staple food after rice in most of the rural areas. Finger millet is a highly nutritious crop with the highest amount of Calcium and Potassium content out of all cereal and millets. It contains a high amount of dietary fiber and have the ability of lowering blood glucose and cholesterol levels. Recently increasing attention is paid to improve finger millet due to above qualities and its inherent capacity to tolerate several abiotic stresses including water deficit and its adaptability to marginal soils with low fertility (Gana et al., 2013).

Germplasm is the basic raw material for any crop improvement programme. Characterization of germplasm accessions to identify true genetic diversity is also essential to use in crop improvement. About 200 finger millet germplasm accessions are being conserved at the seed gene bank of the Plant Genetic Resource Centre (PGRC), Gannoruwa, Sri Lanka. Some of those germplam accessions have been characterized by Kannagara et al., (2011) and Wakista et al., (2015a, 2015b, 2015c and 2015d) using microsatellite markers and by Senanayaka et al., (2008) using AFLP markers. But largely those accessions are uncharacterized.

Multivariate statistical techniques are widely used in analysis of genetic diversity irrespective of whether it is morphological, biochemical or molecular marker-based. Among the multivariate techniques Principal Component analysis (PCA) and cluster analysis are very useful in germplasm characterization. Multivariate analysis has been used frequently in genetic diversity analysis many crops such as finger millet (Dagnachew et al., 2012, Ulaganathan \& Nirmalakumari, 2015) and rice (Gana et al., 2013).

This study was undertaken to characterize some randomly selected conserved finger millet germplasm accessions using morphological markers to reveal their genetic relatedness.

\section{MATERIALS \& METHODS}

\subsection{Plant Material}

Randomly selected 24 finger millet germplasm accessions obtained from the ex situ conserved accessions at the seed gene bank of Plant Genetic resource Centre (PGRC), Gannoruwa, Sri Lanka were used in this study (Table 1). These 24 accessions comprised of 19 local accessions collected from different geographical locations, two (02) Indian accessions, two (02) Zimbabwean accessions and two recommended Sri Lankan varieties. Seeds of the germplasm accessions were obtained from PGRC Gannoruwa.

Table 1. Details of the 24 finger millet germplasm accessions used for the study

\begin{tabular}{|c|c|c|c|c|}
\hline 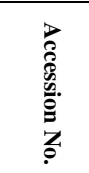 & 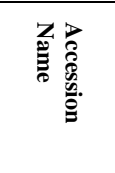 & 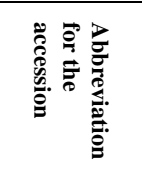 & 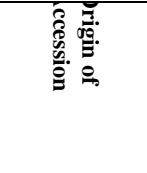 & 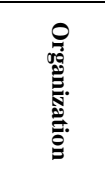 \\
\hline 000122 & $\begin{array}{l}\text { Kobey } \\
\text { Kurakkan }\end{array}$ & $\begin{array}{l}\text { KOKU } \\
\text { (MONERA) }\end{array}$ & Moneragala & PGRC \\
\hline 000258 & Kurakkan & $\begin{array}{l}\text { KU } \\
\text { (HAMBA)-1 }\end{array}$ & Hambanthota & PGRC \\
\hline 000923 & RAG15-6 & INDIA-1 & India & Unknown \\
\hline 000959 & Kurakkan & $\begin{array}{l}\text { KU } \\
\text { (N.ELIYA) }\end{array}$ & NuwaraEliya & PGRC \\
\hline 000963 & CO-10 & INDIA-2 & India & $\begin{array}{l}\text { RARS/ } \\
\text { AK }\end{array}$ \\
\hline 000967 & Line 40 & $\begin{array}{l}\text { L40 } \\
\text { (HAMBA) }\end{array}$ & Hambantota & $\begin{array}{l}\text { RARS/ } \\
\text { AK }\end{array}$ \\
\hline 001233 & $\begin{array}{l}\text { Kalugal } \\
\text { Kurakkan }\end{array}$ & $\begin{array}{l}\text { KLKU } \\
\text { (MATALE) }\end{array}$ & Matale & PGRC \\
\hline 001815 & $\begin{array}{l}\text { Bala } \\
\text { Kurakkan }\end{array}$ & $\begin{array}{l}\text { BAKU } \\
\text { (KANDY) }\end{array}$ & Kandy & PGRC \\
\hline 003011 & Kurakkan & $\begin{array}{l}\text { KU } \\
\text { (HAMBA)-2 }\end{array}$ & Hambanthota & PGRC \\
\hline
\end{tabular}


Characterization of Some ex situ Conserved Finger Millet Germplasm Accessions in Sri Lanka

\begin{tabular}{|l|l|l|l|l|}
\hline 003021 & $\begin{array}{l}\text { Maha } \\
\text { Mora } \\
\text { Kurakkan }\end{array}$ & $\begin{array}{l}\text { MMKU } \\
\text { (HAMBA) }\end{array}$ & Hambantota & PGRC \\
\hline 004989 & Kurakkan & $\begin{array}{l}\text { KU } \\
\text { (PUTTA) }\end{array}$ & Puttalam & PGRC \\
\hline 006580 & Kurakkan & $\begin{array}{l}\text { KU } \\
\text { (MONERA) }\end{array}$ & Moneragala & PGRC \\
\hline 006586 & Kurakkan & $\begin{array}{l}\text { KU } \\
\text { (MATALE) }\end{array}$ & Matale & PGRC \\
\hline 007089 & Kurakkan & $\begin{array}{l}\text { KU } \\
\text { KURUNE) }\end{array}$ & Kurunegala & PGRC \\
\hline 007109 & $\begin{array}{l}\text { SDFM } \\
1143\end{array}$ & $\begin{array}{l}\text { ZIMBABWE } \\
-1\end{array}$ & Zimbabwe & ICRISAT \\
\hline 007123 & $\begin{array}{l}\text { SDFM } \\
2564\end{array}$ & $\begin{array}{l}\text { ZIMBABWE } \\
-2\end{array}$ & Zimbabwe & ICRISAT \\
\hline 007769 & Kurahan & $\begin{array}{l}\text { KU } \\
\text { (POLON) }\end{array}$ & Plonnaruwa & PGRC \\
\hline 007777 & Kurakkan & $\begin{array}{l}\text { KU } \\
\text { (BADULLA) }\end{array}$ & Badulla & PGRC \\
\hline 008389 & $\begin{array}{l}\text { Haramus } \\
\text { Kurakkan }\end{array}$ & $\begin{array}{l}\text { HAKU } \\
\text { (ANU) }\end{array}$ & Anuradhapra & PGRC \\
\hline 008470 & $\begin{array}{l}\text { Makala } \\
\text { Kurakkan }\end{array}$ & $\begin{array}{l}\text { MAKU } \\
\text { (MONERA) }\end{array}$ & Moneragala & PGRC \\
\hline 008796 & Kurakkan & $\begin{array}{l}\text { KU } \\
\text { KEGALLE) }\end{array}$ & Kegalle & PGRC \\
\hline 009083 & $\begin{array}{l}\text { Kaha } \\
\text { Kurakkan }\end{array}$ & $\begin{array}{l}\text { KAKU } \\
\text { (N.ELIYA) }\end{array}$ & NuwaraEliya & PGRC \\
\hline 09294 & Ravi & $\begin{array}{l}\text { RAVI } \\
\text { d variety }\end{array}$ & PGRC \\
\hline 10326 & Ravana & RAVANA & $\begin{array}{l}\text { Recommende } \\
\text { variety }\end{array}$ & PGRC \\
\hline
\end{tabular}

International Plant Genetic Resource Institute (IPGRI) descriptors developed for finger millet.

\subsection{Statistical Analysis}

\subsubsection{Descriptive statistics}

Descriptive statistics mean, minimum, maximum and standard deviation for each character were obtained using MINITAB17 software.

\subsubsection{Principal Component Analysis}

Principal Component Analysis for 17 quantitative characters was performed using MINITAB14 software. As suggested by Johnson \& Wichern (1988) principal components with Eigen values greater than one was considered.

\subsubsection{Cluster analysis}

\subsection{Morphological Characterization}

\subsubsection{Experimental Design}

Seeds of each accession were sown in small plastic pots filled with a mixture of soil and compost (3:1), in the green house of the Department of Botany of University of Sri Jayewardenepura. About 20 days old seedlings were transplanted separately in to large pots (22 $\mathrm{cm}$ diameter) filled with the same mixture of soil and compost as each pot contained three (03) plants. All accessions were arranged in a Randomized Complete Block Design (RCBD) with 12 individuals from each accession.

\subsubsection{Data Collection}

Fourteen quantitative characters [days to flowering, flag leaf length ( $\mathrm{mm})$, flag leaf width $(\mathrm{mm})$, plant height $(\mathrm{cm})$, clum thickness $(\mathrm{mm})$, finger number, finger length $(\mathrm{mm})$, finger width $(\mathrm{mm})$, clum branching, days to maturity, weight of sun dried ear $(\mathrm{g})$, weight of grain per ear $(\mathrm{g})$, 1000 grain weight $(\mathrm{g})$ and number of productive tillers] were recorded at different growth stages of the crop. Characters were scored following

Hierarchical clustering of complete linkage method with squared Euclidian distance was performed using MINITAB17 software. Data of all quantitative characters were standardized to a mean of zero and a variance of one before clustering to avoid bias that arise due to differences in measurement scales.

\section{RESULTS \& DISCUSSION}

Twenty two finger millet germplasm accessions and two recommended finger millet varieties were characterized using 14 quantitative characters. Out of 14 quantitative characters one character (number of productive tillers) was monomorphic across all 24 accessions and other 13 characters were polymorphic. Wide range of genetic variability was observed for different characters and their mean, minimum and maximum values are given in Table 2 .

Earliness is an important agronomic trait considered while breeding for high yielding varieties. The number of days to flowering ranged from 66.92 to 94.08 with an average value of 81.26. Germplasm accession Co-10 
(collected from India) had lowest and Makala Kurakkan collected from Moneragala had the highest value for days to flowering. Plant height and culm thickness also are important traits as those affect on the resistance to lodging.

Accession KU (Monera) - collected from Moneragala showed shortest plant and accession Haramus Kurakkan collected from Anuradhapura showed plant highest.

Table 2. Genetic variability for 14 quantitative characters in 24 finger millet accessions

\begin{tabular}{|c|c|c|c|c|}
\hline Character & Mean & Minimum & Maximum & SD \\
\hline $\begin{array}{l}\text { Days to } \\
\text { flowering }\end{array}$ & 81.26 & 66.92 & 94.08 & 6.57 \\
\hline $\begin{array}{l}\text { Flag leaf } \\
\text { length }(\mathrm{mm})\end{array}$ & 280.82 & 146.00 & 346.25 & 49.55 \\
\hline $\begin{array}{l}\text { Flag leaf width } \\
(\mathrm{mm})\end{array}$ & 8.44 & 6.00 & 12.00 & 1.02 \\
\hline $\begin{array}{l}\text { Plant height } \\
(\mathrm{cm})\end{array}$ & 82.44 & 58.13 & 101.53 & 9.92 \\
\hline $\begin{array}{l}\text { Culm thickness } \\
(\mathrm{mm})\end{array}$ & 21.03 & 16.64 & 26.25 & 2.15 \\
\hline Fingernumber & 6.44 & 4.33 & 8.08 & 1.17 \\
\hline $\begin{array}{l}\text { Finger length } \\
(\mathrm{mm})\end{array}$ & 55.64 & 43.25 & 91.58 & 8.95 \\
\hline $\begin{array}{l}\text { Fingerwidth } \\
(\mathrm{mm})\end{array}$ & 9.37 & 7.92 & 10.33 & 0.51 \\
\hline $\begin{array}{l}\text { Culm } \\
\text { branching }\end{array}$ & 1.66 & 0.42 & 2.92 & 0.72 \\
\hline $\begin{array}{l}\text { Productive } \\
\text { tillers }\end{array}$ & 0.00 & 0.00 & 0.00 & 0.00 \\
\hline Daystomaturity & 125.19 & 96.00 & 146.00 & 13.35 \\
\hline $\begin{array}{l}\text { weight of sun } \\
\text { dried ear }(\mathrm{g})\end{array}$ & 3.05 & 1.11 & 4.60 & 0.90 \\
\hline $\begin{array}{l}\text { Weight of } \\
\text { grain per ear } \\
\text { (g) }\end{array}$ & 2.45 & 0.94 & 3.82 & 0.77 \\
\hline $\begin{array}{l}1000 \text { grain } \\
\text { weight }(\mathrm{g})\end{array}$ & 2.19 & 1.76 & 2.64 & 0.22 \\
\hline
\end{tabular}

SD - Standard Deviation
Knowledge on the association between yield and other biometrical traits provide ample opportunities for improvement of crop. The correlation between characters may exist due to various reasons. The association of all quantitative characters was estimated by correlation analysis (Table 3). Out of all studied quantitative characters, days to flowering (days to flowering (0.485), flag leaf width (0.627), flag leaf length (0.710), plant height $(0.636)$, culm thickness (0.408), finger length (0.505), finger width (0.406), days to maturity (0.723) and weight of sun dried ears (0.982) had significant and positive correlation with weight of grain per ear at $\leq 0.005$ level. Weight of grain per ear shows positive correlation with the highest number of characters indicated that all those characters including days to flowering, flag leaf width, flag leaf length, plant height, culm thickness, finger length, finger width, days to maturity and weight of sun dried ears could be simultaneously improved and it also suggested that increasing any one of them would lead to improvement of the other character. Significant and positive association of grain yield per plant with days to flowering, productive tillers per plant, plant height, 1000 grain weight, flag leaf sheath length, days to maturity, flag leaf blade length and finger width have been reported (Ulaganathan \& Narmalakumari., 2015), with days to flowering, flag leaf sheath length, flag leaf blade length and 1000-grain weight (Kadam et al., 2009) and productive tillers per plant (Dagnachew et al., 2012).

Grain yield per plant was equal to the weight of grain per ear with respect to all accessions used in this study as there were no productive tillers. Significant negative correlation (at $\leq 0.005$ level) observed for days to flowering with clum branching (-0.436) indicated increasing one character would lead to decrease in another character. The character 1000-grain weight did not show any significant correlation with any of other characters. 
Table 3. Phenotypic correlation coefficient for 13 quantitative characters in 24 finger millet accessions

\begin{tabular}{|l|l|l|l|l|l|l|l|l|l|l|l|l|l|}
\hline & DF & FLW & FLL & PH & CT & FN & FL & FW & CB & DM & WSDE & WGE & $\begin{array}{l}1000 \\
\text { GW }\end{array}$ \\
\hline DF & 1.000 & & & & & & & & & & & & \\
\hline FLW & 0.205 & 1.000 & & & & & & & & & & & \\
\hline FLL & $0.414^{*}$ & $0.721^{*}$ & 1.000 & & & & & & & & & & \\
\hline PH & 0.074 & $0.425^{*}$ & $0.580^{*}$ & 1.000 & & & & & & & & & \\
\hline CT & 0.031 & $0.451^{*}$ & $0.635^{*}$ & $0.665^{*}$ & 1.000 & & & & & & & & \\
\hline FN & -0.106 & $0.489^{*}$ & $0.608^{*}$ & 0.321 & $0.668^{*}$ & 1.000 & & & & & & & \\
\hline FL & 0.206 & $0.530^{*}$ & 0.399 & $0.414^{*}$ & 0.281 & -0.144 & 1.000 & & & & & & \\
\hline FW & 0.256 & 0.247 & 0.340 & 0.343 & 0.186 & -0.119 & 0.278 & 1.000 & & & & & \\
\hline CB & $-0.436^{*}$ & 0.075 & 0.187 & 0.235 & 0.309 & 0.353 & 0.014 & 0.315 & 1.000 & & & & \\
\hline DM & $0.440^{*}$ & 0.351 & $0.461^{*}$ & $0.682^{*}$ & $0.414^{*}$ & -0.073 & $0.622^{*}$ & 0.384 & 0.018 & 1.000 & & & \\
\hline WSDE & $0.457^{*}$ & $0.674^{*}$ & $0.722^{*}$ & $0.634^{*}$ & $0.469^{*}$ & 0.263 & $0.517^{*}$ & $0.411^{*}$ & -0.025 & $0.718^{*}$ & 1.000 & & \\
\hline WGE & $0.485^{*}$ & $0.627^{*}$ & $0.710^{*}$ & $0.636^{*}$ & $0.408^{*}$ & 0.203 & $0.505^{*}$ & $0.406^{*}$ & -0.054 & $0.723^{*}$ & $0.982^{*}$ & 1.000 & \\
\hline 1000GW & 0.262 & 0.006 & -0.048 & 0.048 & -0.082 & -0.014 & -0.065 & -0.155 & -0.140 & 0.365 & 0.134 & 0.136 & 1.000 \\
\hline
\end{tabular}

*Significant at $\mathrm{P} \leq 0.05$ level

DF - Days to flowering, FLW - Flag leaf width(mm), FLL - Flag leaf length(mm), PH- Plant height (cm), CT - Culm thickness(mm), FN - Finger number, FLM - finger length(mm), FW - Finger width (mm), CB - Culm branching, DM - Days to maturity, WSD - Weight of sun dried ear(g), WGE Weight of grain per ear(g), 1000GW - 1000 grain weight (g)

Table 4. Principal Components showing the Eigen values, proportion of variation and total proportion of variation across axis

\begin{tabular}{|l|l|l|l|}
\hline Principal component & Eigen value & Variation $(\%)$ & $\begin{array}{l}\text { Total variation explained } \\
\text { across axis (\%) }\end{array}$ \\
\hline 1 & 5.58 & 42.9 & 42.9 \\
\hline 2 & 2.21 & 17.0 & 59.9 \\
\hline 3 & 1.38 & 10.6 & 70.5 \\
\hline 4 & 1.07 & 8.3 & 78.8 \\
\hline 5 & 0.87 & 6.7 & 85.5 \\
\hline 6 & 0.65 & 5.0 & 90.5 \\
\hline 7 & 0.47 & 3.6 & 94.1 \\
\hline 8 & 0.30 & 2.3 & 96.5 \\
\hline 9 & 0.21 & 1.6 & 98.1 \\
\hline 10 & 0.10 & 0.8 & 98.9 \\
\hline 11 & 0.08 & 0.6 & 99.5 \\
\hline 12 & 0.05 & 0.4 & 99.9 \\
\hline 13 & 0.01 & 0.1 & 100.0 \\
\hline & & & \\
\hline
\end{tabular}


Table 5. Principal Component analysis for 13 quantitative traits in 24 finger millet germplasm accessions - non-rotated loadings

\begin{tabular}{|l|l|l|l|l|l|}
\hline Character & PC1 & PC2 & PC3 & PC4 & PC5 \\
\hline Days to flowering & 0.181 & 0.423 & -0.227 & 0.220 & 0.413 \\
\hline Flag leaf width $(\mathrm{mm})$ & 0.318 & -0.103 & -0.140 & 0.295 & -0.186 \\
\hline Flag leaf length $(\mathrm{mm})$ & 0.363 & -0.148 & -0.155 & 0.219 & 0.161 \\
\hline Plant height $(\mathrm{cm})$ & 0.329 & -0.115 & 0.117 & -0.305 & -0.138 \\
\hline Culm thickness $(\mathrm{mm})$ & 0.286 & -0.341 & -0.091 & -0.122 & -0.082 \\
\hline Finger number & 0.168 & -0.494 & -0.435 & 0.032 & 0.114 \\
\hline Finger length $(\mathrm{mm})$ & 0.261 & 0.162 & 0.309 & 0.105 & -0.570 \\
\hline Finger width (mm) & 0.201 & 0.051 & 0.536 & 0.074 & 0.566 \\
\hline Culm branching & 0.060 & -0.456 & 0.364 & -0.320 & 0.238 \\
\hline Days to maturity & 0.327 & 0.257 & 0.130 & -0.378 & -0.107 \\
\hline Weight of sun dried ear $(\mathrm{g})$ & 0.388 & 0.122 & -0.050 & 0.059 & 0.028 \\
\hline Weight of grain per ear $(\mathrm{g})$ & 0.380 & 0.160 & -0.038 & 0.058 & 0.043 \\
\hline 1000 grain weight $(\mathrm{g})$ & 0.041 & 0.268 & -0.398 & -0.663 & 0.118 \\
\hline
\end{tabular}

Principal Component Analysis (PCA) was performed for 13 polymorphic quantitative characters. The principal component analysis (PCA) can be used to identify the plant traits which contribute the most for the observed variation among the studied finger millet germplasm accessions. The PCA results revealed that the first five components with Eigen value of greater than 0.87 contribute about $85.5 \%$ of total variability in 24 finger millet germplasm accessions involving all the 13 quantitative characters studied (Table 4). According to Johnson \& Withern (1988) principal component with Eigen values greater than one should be considered. But fifth PC with Eigen value 0.87 was also considered as it also was a considerable value. A variance of $42.9 \%, 17.0 \%, 10.6 \%, 8.3 \%$ and $6.7 \%$ were extracted from the first to the fifth component respectively.

Table 5 shows the corresponding eigen values which gives an idea about the importance of traits towards the principal components. First principal component accounted for $42.9 \%$ of the total variation in the population. As shown in Table 5, Flag leaf width (0.318), Flag leaf length (0.363), Plant height (0.329), Days to maturity (0.327), Weight of sun dried ear (0.388) and
Weight of grain per ear (0.380)contributed more to the variation in $\mathrm{PC} 1$ indicating their significant importance for the first principal component. All traits contributed positive to the first component. Second principal component contributed 59.9\% of total variation. Characters that contributed to the second component include Days to flowering (0.423), culm thickness (-0.341), finger number $(-0.494)$ and culm branching $(-0.456)$. The third principal component contributed for $70.5 \%$ of the total variation.

The variation in the third principal component was mainly due to finger number (-0.435), finger length (0.309), finger width (0.536), culm branching (0.364) and 1000 grain weight (0.398). Likewise, Plant height (-0.305), Culm branching $(-0.320)$, Days to maturity $(-0.378)$ and 1000 grain weight $(-0.663)$ were the major contributor to the variation in the fourth principal component. Fourth principal component cumulatively accounted for $78.8 \%$ of the total variation in the population. The fifth principal component cumulatively contributed $85.5 \%$ of the total variation. The variability in the fifth component was attributed mainly due to Days to flowering (0.413) finger length (-0.570) and finger width $(0.566)$. 
Data from first two components were used to derive PCA score plot and loading plot (Figure 1 and 2). The studied 24 accessions were divided into four groups (A, B, C and D) based on the first two principal components as shown in PCA score plot (Figure 1). Group A comprised of two local accessions [KU(MONERA) - Kurakkan collected from Moneragala, KAKU(N.ELIYA) KahaKurakkan collected from NuwaraEliya], one exotic accessions (ZIMBABWE-2) and two recommended varieties (RAVI and RAVANA) while five local accessions [BAKU(KANDY) BalaKurakkan collected from Kandy, KU(HAMBA)-2 - Kurakkan collected from Hambanthota, KU(MATALE) - Kurakkan collected from Matale, L40(HAMBA) - line 40 collected from Hambanthotaand MAKU(MONERA) - Makala Kurakkan collected from Moneragala were in group B. Group C comprised of five local accessions $[\mathrm{KU}(\mathrm{POLON})$ - Kurakkan collected from Polonnaruwa, KU(N.ELIYA)-Kurakkan collected from NuwaraEliya, KOKU(MONERA)- KobeyKurakkan collected from Moneragala, KU(BADULLA)-Kurakkan collected from Badulla and KU(PUTTA) Kurakkan collected from Puttalum] one exotic accession (INDIA-2). Local accessions; KU(HAMBA)-1- Kurakkan collected from Hambanthota, KU(KURUNE)-Kurakkan collected from Kurunegala, KU(KEGALLE) - Kurkkan collected from Kegalle, MMKU (HAMBA) Maha Mora Kurakkan collected from Hambanthota and one Indian accessions (INDIA-1) were in group D (Figure 1).

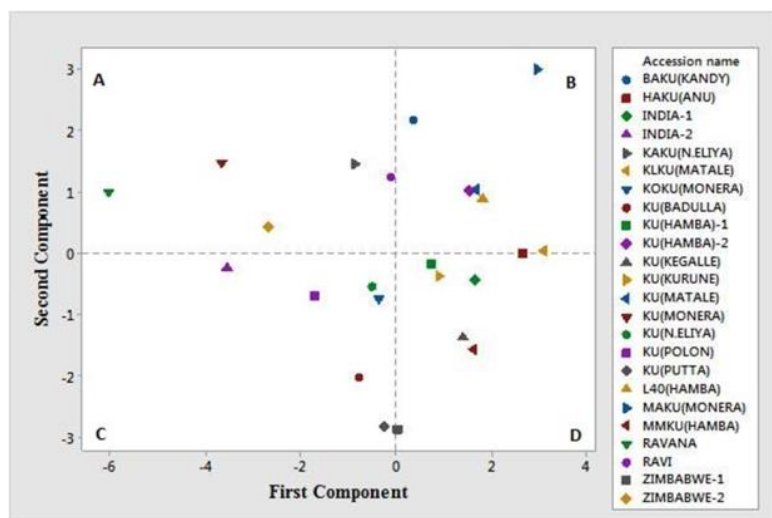

Figure 1. Score plot showing the grouping of studied finger millet germplasm accessions
Similarly, the recorded characters were divided into two groups ( $\mathrm{X}$ and $\mathrm{Y}$ ) depending on the first two principal components as shown in PCA loading plot (Figure 2).

The group X consists of Days to flowering, days to maturity, Finger length, Finger width, weight of sun dried ear, weight of grain per ear and 1000 grain weight whereas Plant height, Flag leaf length, flag leaf width, culm thickness, culm branching and finger number had been grouped in the group $\mathrm{Y}$.

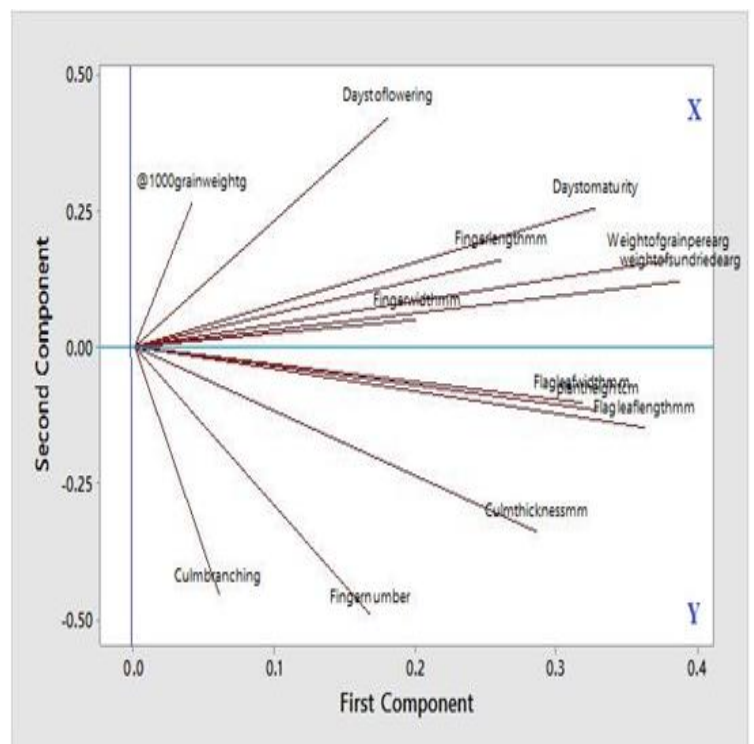

Figure 2. Loading plot showing the grouping of the 13 quantitative characters

Dendrogram constructed based on squared Euclidian distance comprised of four (04) sub clusters as Cluster I, Cluster II,Cluster III and Cluster IV (figure 3). Cluster I comprised of one local accession collected from Moneragala(KU(MONERA)) and one accession collected from India (INDIA-2) and one local recommended variety (RAVANA).

A local accession collected from Moneragalanamed as Makala Kurakkan (MAKU(MONERA) separated from remaining clusters at the similarity level of about 30 showing their genetic dissimilarity with the accessions of four clusters. Cluster II consisted 
of five accessions and three of them were local accessions [KU(POLON), KAKU(N.ELIYA) and BAKU(KANDY)] collected from Plonnaruwa, NuwaraEliya and Kandy.

A Zimbabwian accession (ZIMBABWE-2) and other recommended variety (RAVI) were other two constituents of that cluster. Kurakkan accession collected from Polonanaruwa $(\mathrm{KU}(\mathrm{POLON}))$ has groped together with Zimbabwian accession (ZIMBABWE-2) within a sub group of that cluster showing their genetic relatedness even when they represent different geographical origins. Eight accessions were within cluster III and seven of them were local accessions [HAKU(ANU)-Haramuskurakkan collected from Anuradhapura, KU(HAMBA)-2Kurakkan collected from Hambanthota, KLKU(MATALE)-KalugalKurakkan collected from (Matale), KU(MATALE)-Kurakkan collected from Matale, L40(HAMBA)-Line 40 collected from Hambanthota, KU(KURUNE)Kurakkan collected from Kurunegala, KU(HAMBA)-1-Kurakkan collected from Hambanthota] and only one (INDIA-1) was with exotic origin.

Though three accessions collected from same districtsHambanthota [KU(HAMBA)-2, L40(HAMBA) and KU(HAMBA)-1] could be seen within this cluster those were sub grouped with other three accessions collected from three different districts Anuradhapura, Matale and Kurunegala respectively.

This observation proves that genetic relatedness is irrespective to their geographic origin. Cluster IV comprised of six local accessions [KU(PUTTA)-Kurakkan collected from Puttalum, KU(KEGALLE)-Kurakkan collected from Kegalle, MMKU(HAMB)-Maha Mora Kurakkan collected from Hambanthota, KU(BADULLA)-Kurakkan collected from Badulla, KU (N.ELIYA)-Kurakkan collected from NuwaraEliya, KOKU(MONERA)KobeyKurakkan collected from Moneragala] and one accession collected from Zimbabwe (ZIMBABWE-1) (Figure 3).

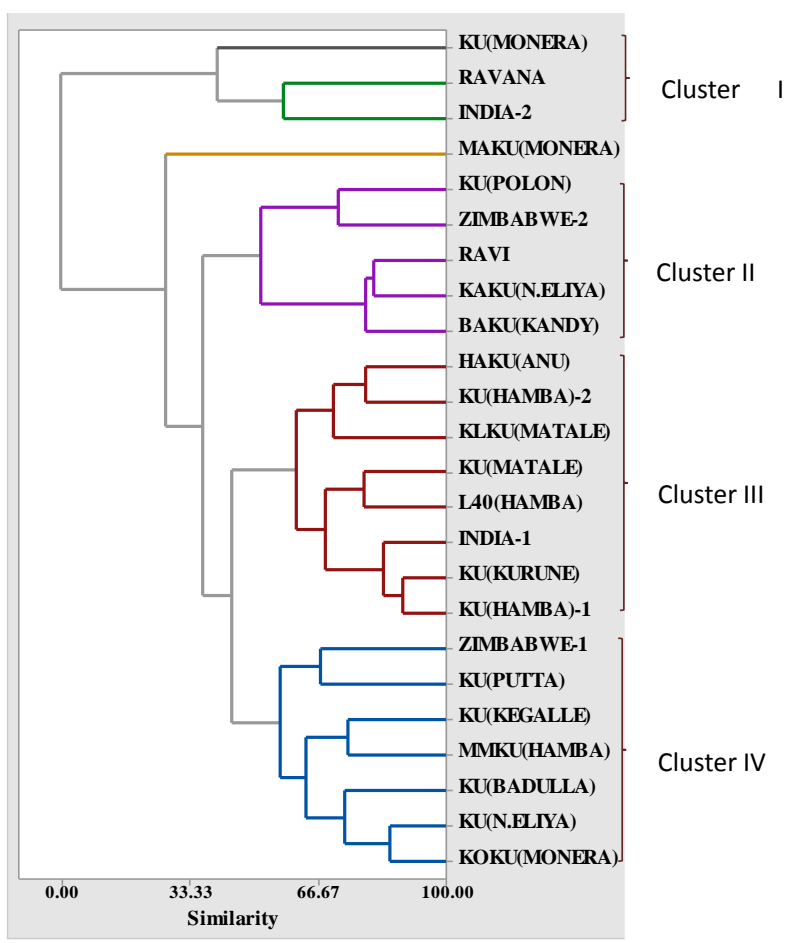

Figure 3. Dedrogram of finger millet germplasm accessions constructed based on squared Euclidian distance

This clustering pattern could be used in choosing diverse genotypes to use in breeding and conservation programmes. The crossing among the genetically distant accessions would produce individuals with high heterosis. The accession collected from Moneragala (MAKU MONERA) formed solitary cluster and found to be more variable.

\section{CONCLUSIONS}

Characterization of available germplasm accessions is very important in crop improvement programmes and morphological markers play an important role in germplasm characterization. Fourteen quantitative characters were used in the study and Principal Component Analysis revealed that days to flowering, flag leaf width, flag leaf length, plant height, culm thickness, finger length, finger width, days to maturity and weight of sun dried ears had significant and positive correlation with 
weight of grain per ear at $\leq 0.005$ level highlighting increasing any one of them would lead to improvement of other character. Significant negative correlation (at $\leq 0.005$ level) observed for days to flowering with clum branching indicated increasing one character would lead to decrease in another character. Studied accessions grouped into four (04) main clusters exhibiting their genetic relatedness and which can be used in breeding and conservation programme of the crop.

\section{ACKNOWLEDGEMENT}

The author would like to acknowledge University Grant Number ASP/6/R/2005/07 of University of Sri Jayewardenepura, and Plant Genetic Resource Centre, Gannoruwa.

\section{REFERENCES}

\section{DAGNACHEW L, KASSAHUM T,} MASRESHA F \& SANTIE DE V. Multivariate analysis for quantitative traits in finger millet (Eleusine coracana subsp.coracana) populations collected from eastern and southestern Africa: Detection for patterns of genetic diversity, International Journal of Agricultural Research. 2012; 7(6):303-314.

GANA AS, SHABA SZ \& TSADO EK. Principal component analysis of morphological traits in thierty-nine accessions of rice (Oryza sativa L.) grown in a rainfed lowlandecology of Nigeria. J Plant Breeding. Crop Sci. 2013;5:120126.

JOHNSON RA \& WICHERN DW. Applied Multivariate Statistical Analysis. Prentice Hall, Englewood Cliffs, NJ. 1988.

KADAM DD, KULKARNI SR \& JADHAV BS. Genetic variability, correlation and path analysis in finger millet, J Maharashtra AgricUniv 2009; 34(2):131-134.
KANANGARA UM, WEERASENA OVDSJ, \& DASANAYAKA PN. Genetic diversity Assessment of finger millet using microsatellite markers, Proceedings of Fourth Annual Scientific Sessions, Institute of Biochemistry, Molecular Biology and Biotechnology, University of Colombo, Sri Lanka. 2011; 36.

SENANAYAKA SMC, DASANAYAKA PN \& WEERASENA OVDSJ. Preliminary studies on genetic differentiation of finger millet accessions using AFLP markers. Proceedings of Third Annual Scientific Sessions, Institute of Biochemistry, Molecular Biology and Biotechnology, University of Colombo, Sri Lanka, 2008; 34.

ULAGANATHAN V \& NARMALAKUMARI A. Finger millet germplasm characterization and evaluation using principal component analysis, SABRAO Journal of Breeding and Genetics 2015; 47 (2):79-88.

WAKISTA PW, DASANAYAKA PN, ILLEPERUMA RJ \& PERERA SACN. SSR Marker Based Molecular Characterization of Finger Millet accessions of India and Anuradhapura District of Sri Lanka, Proceedings of International Forestry and Environment Symposium of the Department of Forestry and Environmental Science, University of Sri Jayewardenepura, Nugegoda, Sri Lanka, 2015a;40.

WAKISTA PW, DASANAYAKA PN, ILLEPERUMA RJ \& PERERA SACN. SSR marker based genetic relatedness of some finger millet (Eleusine coracana) accessions of Sri Lanka, Proceedings of the seventy first annual sessions of Sri Lanka Association for the Advancement of science, 2015b; 15.

WAKISTA PW, DASANAYAKA PN, ILLEPERUMA RJ \& PERERA SACN. SSR markers revealed genetic diversity of some finger millet accessions collected from six districts of Sri Lanka, Proceedings of seventh 
Annual Scientific Sessions, Institute of Biochemistry, Molecular Biology and Biotechnology, University of Colombo, Sri Lanka, 2015c;34.

WAKISTA PW, DASANAYAKA PN, ILLEPERUMA RJ, PERERA SACN \& BANDARA SP. Compilation of an informative SSR marker set for molecular characterization of finger millet (Eleusine coracana L.) germplasm accessions of Sri Lanka. Proceedings of International Conference on Multidisciplinary Approaches, Faculty of Graduate Studies, University of Sri Jayewardenepura, Sri Lanka. 2015d; 217. 